ranging from six months to a year. Visiting professors will not be limited to United States citizens, but will include scientists from overseas. The programme is partially supported by the National Science Foundation. Advance notice will be provided, giving information as to the names of visiting professors and the special fiolds of study in which they will lecture. Students from other institutes and universities will be invited to engage in the research and to study under the supervision of the visiting professors. Further information can be obtained from Dr. C. Richard Robins, Institute of Marine Science, University of Miami, 1 Rickenbacker Causeway, Miami, 49.

\section{Course on High Polymer Chemistry}

A postgraduate course on "High Polymer Chemistry" has been arranged by the Bradford Institute of Technology. The course, which will last for one academic year, is primarily designed for graduates entering, or already engaged in, research or production in those industries connected with plastics, synthetic fibres, surface coating and rubber. The course will include detailed treatment of the principlos of high polymer chemistry together with aspects of polymer physics and a survey of polymer technology, laboratory work introducing research techniques, research projects and colloquia, and general and economic studies. Further information can be obtained from the Registrar, Bradford Institute of Technology, Bradford 7.

University News :

East Anglia

Prof. 'T. A. Bennet-Clark, professor of botany in King's College, University of London, has been appointed professor of botany and dean of the School of Biological Studies.

\section{London}

THE title of professor of oral pathology has been conferred on Mr. I. H. R. Kramer, in respect of his post at the Institute of Dental Surgery, and that of professor of industrial relations on Mr. B. C. Roberts, in respect of his post at the London School of Economics and Political Science. Dr. J. N. Hunt, reader in physiology at Guy's Hospital Medical School, has been appointed to the chair of physiology tenable at that School, and Mr. J. L. Stafford, senior lecturer in hæmatology at St. George's Hospital Medical School, has been appointed to the readership in hrematology tenable at that School.

Yale

THE following have been appointed to the Department of Botany: Theodore Delevoryas, formerly of the University of Illinois, as associate professor (palæobotany); Bruce C. Carlton, formerly of Stanford University, as assistant professor (biochemical genetics); James Cronshaw, formerly of the C.S.I.R.O., Australia, as assistant professor (electron microscopy); G. Benjamin Bouck, formerly of Harvard Univorsity, as instructor (electron microscopy); Beatrice M. Sweeney, formerly of Scripps Institute, La Jolla, California, as lecturer (algal physiology).

\section{Announcements}

UNDER the terms of the scheme to commemorate the late Lord Rutherford of Nelson, Sir Nevill Mott, Master of Gonville and Caius College and Cavendish professor of exporimental physics in the University of Cambridge, has been appointed Rutherford
Memorial Lecturer for 1962, to lecture during October-November in Uganda (Makerere University College), Konya (Royal College, Nairobi), Southern Rhodesia (University College of Rhodesia and Nyasaland, Salisbury), Nigeria (University College, Ibadan, and Zaria) and Ghana (Accra and Kumasi).

DR. G. E. R. Deacon, director of the National Institute of Oceanography, has been awarded the Agassiz Medal by the U.S. National Academy of Sciences for his contribution to the development of oceanography in the exploration and interpretation of the hydrography of the Southern Ocean.

Dr. P. Gross, principal scientist of the Fulmer Research Institute, has boen appointed to the Board of Directors of the Institute. Mr. E. A. G. Liddiard, dircctor of research, remains as senior executive director with responsibility for administration.

Prof. J. B. Spenkman, head of the Department of Textile Industries in the University of Leeds, has been elected president of the Textile Institute.

A Neurospora Newsletter has been initiated to facilitate communication among research workers interested in this organism. The Newsletter, the first of which appeared on May 1, will be sent, free of charge, to all investigators requesting it from the editor, B. J. Bachmann, Department of Microbiology, Yale University, New Haven 11, Connecticut.

A Fwo meeting on the theme "Soil Organic Matter", the last in the present session of the Welsh Soils Discussion Group, will be held at Aber, near Bangor, on May 9. Further information can be obtainod from Mr. James A. Taylor, Department of Geography, University College of Wales, Alexandra Road, Aberystwyth.

A SPECIAL short course on "Technology of the Newer Plastics and Polymers" will be held in the Bradford Institute of Technology during June 22-23. Subjects under discussion will include: newer plastics and polymers; polyvinyl chloride; polypropylene; acetal resins; polyurethanes. Further information can be obtained from the Registrar, Bradford Institute of Technology, Bradford 7.

THE second congress of the International Federation of Societies of Cosmotic Chomists, organized by the Socioty of Cosmotic Chemists of Great Britain, will be held in the School of Pharmacy, University of London, during July $2 \div 5$. Subjects under discussion will include: surface and physical chemistry; experimental methods; properties of skin; treatment of skin and mouth. Further information can be obtained from A. Herzka, Pressurized Packaging Consultants, Ltd., Ashbourne House, Alberon Gardens, London, N.W.11.

AN intornational symposium on "Problems of Man in Space", organized jointly by the International Astronautical Federation and the International Academy of Astronautics and supported by Unesco, the International Atomic Energy Agency and tho World Health Organization, is to be held in Paris during Oetober 29-November 2. The programme will be devoted mainly to the problems of ecophysiology, psychophysiology and data acquisition, analysis and control, and there will be an exhibition showing the techniques used to study these problems and the equipment developed for survival in space. Further information can be obtained from Unesco, Place de Fontenoy, Paris 7e. 